anales de psicología / annals of psychology

2019, vol. 35, nº 1 (january), 116-123

http://dx.doi.org/10.6018/analesps.35.1.309801
(C) Copyright 2019: Editum. Servicio de Publicaciones de la Universidad de Murcia. Murcia (Spain) ISSN print edition: 0212-9728. ISSN on line edition (http://revistas.um.es/analesps): 1695-2294

On line edition License Creative Commons 4.0: BY-NC-ND

\title{
Health and Safety at Work in the Transport Industry (TRANS-12): Factorial Structure, Reliability and Validity
}

\author{
Jordi Assens-Serra ${ }^{1}$, María-José Serrano-Fernández² ${ }^{*}$, Joan Boada-Grau² ${ }^{2}$ Maria Boada-Cuerva², \\ Sergi Macip-Simón ${ }^{2}$, and Andreu Vigil-Colet ${ }^{2}$
}

1 Business School EADA, Barcelona (Spain) 2 Universidad Rovira $i$ Virgili (URV), Tarragona (Spain)

\begin{abstract}
Título: Salud y seguridad laboral en la industria del transporte (TRANS12): estructura factorial, fiabilidad y validez.

Resumen: Antecedentes: Este estudio expone las propiedades psicométricas de la escala TRANS-18 y de una versión más corta, el TRANS-12, ambos diseñados para detectar conductas seguras (personales y relacionadas con el vehículo) y trastornos psicofisiológicos entre conductores profesionales. Método: La investigación se divide en dos. Estudio 1, estructura factorial, fiabilidad y validez del TRANS-18, y Estudio 2, se estudian los mismos aspectos en el TRANS-12. Los participantes en ambos estudios fueron residentes en España. 272 conductores profesionales participaron en el Estudio 1, mientras que el Estudio 2 participaron 326 conductores. Resultados: Se realizó un análisis factorial confirmatorio para ambos estudios. Los resultados del Estudio 1 confirman una estructura interna de tres factores relacionados con los trastornos psicofisiológicos y las conductas de seguridad personales y con el vehículo, pero el TRANS-18 original se descarta por no ajustarse al modelo. Con respecto al Estudio 2, los resultados muestran un buen ajuste del modelo de tres factores, la fiabilidad apropiada y la evidencia de validez. Conclusiones: Concluimos considerando la idoneidad de las propiedades psicométricas del TRANS-12 y su utilidad para identificar comportamientos seguros en el trabajo en la industria del transporte.

Palabras clave: Conductas de seguridad; Trastornos psicofisiológicos; Transporte; escala; Estudio intrumental.
\end{abstract}

\section{Introduction}

The European Commission's strategy for the period 20142020 is aimed at protecting the more than 217 million workers in the EU from occupational accidents and diseases. It lays down that improvements need to be made in the areas of employee health and safety and the prevention of workrelated diseases (Occupational Safety and Health, 2014). The results of the evaluation of the 2007-2012 Occupational Safety and Health (OSH) strategy confirm the value of an EU strategic framework (European Commission, 2014).

In 2014 the transport and storage sector was the second most affected by fatal accidents at work of all the industries surveyed by Eurostat (Eurostat, 2016) in the EU-28.

According to the Occupational Safety and Health Administration (OSHA), in the USA in 2015 there were close to 2.9 million non-fatal workplace injuries and illnesses reported by private industry employers. Nevertheless, six of the private industry sectors reported a decline in the rate of injuries and illnesses that year, including the transport industry (Department of Labor, Bureau of Labor Statistics, 2016).

* Correspondence address [Dirección para correspondencia]

María José Serrano-Fernández. Faculty of Education Sciences and Psychology. Campus Sescelades. Ctra Valls, s/n. 43005. Tarragona (Spain).

E-mail: mariajose.serrano@urv.cat

(Article received: 9-11-2017; revised: 23-3-2018; accepted: 2-6-2018)
Abstract: Background: This study sets out the psychometric properties of the TRANS-18 scale and of a shorter version, the TRANS-12, both designed to detect safe behaviors (personal and vehicle-related) and psychophysiological disorders among professional drivers. Method: The investigation was divided into Study 1, into the factorial structure, reliability and validity of the TRANS-18, and Study 2, looking into the same aspects of the TRANS-12. The participants in both studies were resident in Spain. 272 professional drivers took part in Study 1, while Study 2 had 326 participants. Results: A confirmatory factor analysis was carried out for both studies. The results for Study 1 confirm an internal structure of three factors related to psychophysiological disorders and personal and vehicle-related safety behaviors, but the original TRANS-18 is discarded because it does not fit the model. With regard to Study 2, the results show a good fit of the three-factor model, appropriate reliability and evidence of validity. Conclusions: We conclude by considering the suitability of the psychometric properties of the TRANS-12 and its utility for identifying safe behaviors in work in the transport industry.

Keywords: Safety behaviors; Psychophysiological disorders; Transport; Scale; Instrumental study.

In Spain, the National Commission for Safety and Health at Work (INSHT, 2015) notes in its guidelines for 2015-2020 that employees in the transport industry have one of the highest prevalence rates of psychosocial hazards and unsafe behaviors.

An outline needs to be given of a series of circumstances that are adversely related to transport workers' health, such as working shifts (Chen et al., 2010; Ulhôa, Marqueze, Kantermann, Skene, \& Moreno, 2011), the demands of the job (Dorrian, Baulk, \& Dawson, 2011, Gómez-Ortiz, Cendales, Useche, \& Bocarejo, 2018), lack of safety motivation (Nahrgang, Morgeson, \& Hofmann, 2011; Seibokaite \& Endriulaitiene, 2012) and excessively long working hours (Wagstaff \& Lie, 2011). Other variables that have potentially adverse effects on psychosocial health include work tension in bus drivers (Ramírez et al., 2013) and taxi drivers (Ramírez et al., 2013) and bus drivers' vulnerability in terms of choosing coping strategies (Dorn, Stephen, Wålberg, \& Gandolfi, 2010). Stress has also been related to a higher accident involvement in drivers (Öz, Özkan, \& Lajunen, 2010). Other studies have found negative effects on drivers' work health associated with job fatigue (Ahsberg, 2000; Gershon, Shinar, Oron-Gilad, Parmet, \& Ronen, 2011; Lin, Wu, Liou, \& Guo, 2017; Useche, Cendales, \& Gómez, 2017a), job stress (Ulhôa et al., 2011; García-Herrero, Lopez-Garcia, Herrera, Fontaneda, Báscones, \& Mariscal, 2017), psychological and phys- 
ical symptoms (Đinđić et al., 2013), states of depression (Álava Urrburu, Huerta Rodríguez, \& Noval Vallina, 2011), drowsiness (Catarino, Spratley, Catarino, Lunet, \& PaisClemente, 2014), lower back pain (Alperovitch-Najenson et al., 2010; Kresal, Roblek, Jerman, \& Meško, 2015; Jadhav, 2016), hypertension (Hirata et al., 2012; Siedlecka, Bortkiewicz, Gadzicka, \& Makowiec-Dabrowska, 2012) and coronary diseases (Chen et al., 2010; Đinđić et al., 2013).

The work demands can influence stress outcomes in such a way that people may perceive high workloads as less aversive if they have some control over work activities (Öz et al., 2010; Cendales-Ayala, Useche, Gómez-Ortiz, \& Bocarejo, 2017). This model can be applied in the transport industry, so it is essential to look at the interaction of these two features in professional drivers. In this sense, the Job-DemandControl (JDC) model by Karasek (1979) provided a theoretical approach that identified job demands and job control as fundamental job characteristics that influence well-being. The main point of this model suggests that jobs that are high on demands and low on control involve the highest risk of illness and low well-being (Häusser, Mojzisch, Niesel, \& Schulz-Hardt, 2010; Cendales-Ayala et al., 2017).

Safety climate has been shown to be a predictor of employees' safety compliance, safety participation and accident rates (Clark, Zickar, \& Jex, 2014). It is also believed that the degree of safety of the behavior helps reduce occupational accident rates (Castilla, 2012). Safety performance is considered to have three components: knowledge, skill and motivation. Whereas the first two factors can be taught and instilled by the organization, motivations are affected by many organizational factors that affect the degree to which safety messages from the company are actually assimilated into job attitudes and behaviors (Credo et al., 2010; Useche et al., 2017b). Organizational factors such as organizational culture, safety policy and safety climate determine to a large extent how safely a professional driver drives (Öz et al., 2010; Gómez-Ortiz et al., 2018).

We have deemed it necessary to draw up a brief instrument in Spanish to evaluate both safe and unsafe behaviors along with the risk that affects the health of employees in the transport industry. Presented here is a shorter version of the TRANS-18 (Boada-Grau, Sánchez-García, Prizmic-Kuzmica, \& Vigil-Colet, 2012).

This study probes psychophysiological disorders (Đinđić et al., 2013), aware that their prevalence in drivers is significant and that they have been related to their professional activity as shown by research carried out into anxiety (Chai, Qu, Sun, Zhang, \& Ge, 2016), depression (Álava Urrburu et al., 2011; Shen et al., 2013), stress (Ulhôa et al., 2011; GarcíaHerrero et al., 2017), digestive disorders (Winkleby, Ragland, \& Syme, 1988), musculoskeletal problems (Tamrin, Yokoyama, Aziz, \& Maeda, 2014; Kresal et al., 2015) and cardiac risk (Chen et al., 2010; Siedlecka et al., 2012; Đinđić et al., 2013) in professional drivers.

\section{Study 1}

\subsection{Objectives}

Objective-1: to analyze the internal structure of the original 18-item scale through confirmatory factor analysis (henceforth CFA); Objective-2: to calculate reliability; and Objective-3: to show evidence of validity.

\subsection{Method}

\subsubsection{Participants}

A total of 272 transport drivers resident in Spain took part in the study (Study 1). Their sector distribution was as follows: general freight $(42.6 \%)$, dangerous freight $(4.1 \%)$, special freight $(3 \%)$, cranes $(1.1 \%)$, intra-urban line passengers $(9.3 \%)$, inter-urban line passengers $(7.4 \%)$, charter passengers $(3 \%)$, ambulances $(5.6 \%)$, taxis $(14.8 \%)$ and others $(9.1 \%)$. Their work in transport took place in the following areas: Europe (14.4\%), Spain (34.1\%), autonomous regions $(19.3 \%)$ and provinces $(32.2 \%) .91 .5 \%$ of the participants were men and $8.5 \%$ women. The average age was 40.37 (SD $=12.44)$.

\subsubsection{Measures}

The Spanish version of the TRANS-18 Scale (Trans; Boada-Grau et al., 2012) has 18 items and 3 sub-factors with 6 items each: psychophysiological disorders of driver $(\alpha=$ .81; "11.- My job has at some time caused me depression problems"), personal safety behaviors ( $\alpha=.80$; "7.- I avoid driving whilst smoking and I don't hold the cigarette, cigar in my hand") and vehicle-related safety behaviors ( $\alpha=.70$; "3.-I use work gloves when I handle and load freight, change a tire, etc."). The response format for this is a five-point scale $(1=$ never, $2=$ rarely, $3=$ sometimes, $4=$ almost always, $5=$ always).

The Spanish version of the Maslach Burnout Inventory General Survey (MBI-GS; Salanova, Schaufeli, Llorens, Peiró, \& Grau, 2000; Schaufeli, Leiter, Maslach, \& Jackson, 1996) consists of 15 items and three subscales. The exhaustion subscale consists of 5 items (e.g. "6.-I am "burnt out' by the job"), the cynicism subscale consists of 4 items (e.g. "9.-I have lost enthusiasm for my job") and the professional efficacy subscale contains 6 items (e.g. "12.-I have accomplished many worthwhile things in this job"). Responses were anchored using a 6-point scale (from never to every day). Internal consistency was .87 (exhaustion), .85 (cynicism) and .78 (professional efficacy).

The Spanish version of the Swedish Occupational Fatigue Inventory (SOFI; Ahsberg, 2000; Ahsberg, Gamberale, \& Kjellberg, 1997; González, Moreno, Garrosa, \& López, $2005)$ enables us to diagnose occupational fatigue. It has 15 items and five subscales: lack of energy ( 3 items; $\alpha=.82$; e.g. "2.-Exhausted"), physical tiredness (3 items; $\alpha=.75$; e.g. "9.- 
I feel hot"), physical discomfort (3 items; $\alpha=.80$; e.g. "3.Numb"), lack of motivation (3 items; $\alpha=.81$; e.g. "10.Indifferent") and drowsiness (3 items; $\alpha=.91$; e.g. "11.Yawning"). Responses are measured using a 10-point anchoring scale (From $1=$ Not at all to $10=$ To a great extent) .

\subsubsection{Procedure}

The data were collected from a Spanish sample of professional drivers. Non-probabilistic sampling for accessibility was used.

\subsubsection{Data analysis}

The AMOS 23.0 program was used in Study $1\left(n_{1}=272\right)$. This makes it possible to specify, estimate, evaluate and present a CFA model in an intuitive diagram that shows possible relationships between the variables. Structural equation modeling (SEM) has advantages for testing the properties of a scale, thus providing a method for examining the underlying structure of latent variables. These are factors that cannot be directly measured, but that can be estimated using other manifest variables (Schumacker \& Lomax, 1996). The global adjustment indexes used in the structural equation models are (Fan \& Sivo, 2007; Lévy-Mangin \& Varela-Mallou, 2006): the root mean square error of approximation (RMSEA $\leq$ $.06)$, the comparative fit index (CFI $\geq .95)$, the Tucker-Lewis index (TLI $\geq .95$ ) and the non-normed fit index (NFI $\geq .95$ ). The SPSS program (23.0) was also used to calculate the reliability of the factors and evidence of validity.

\subsection{Results}

\subsubsection{Confirmatory factor analysis}

The initial model has 18 items and three factors. The model of this 18-item initial version was discarded since it does not fit, showing the following indexes: RMSEA (.08), NFI (.84), TLI (.86) and CFI (.91) (Table 1). However, in order to obtain a suitable fit we proceeded to analyze items that did not have an appropriate saturation. Those items that made the model's fit impossible in the original version were discarded. Thus a total of six items were eliminated, thereby making it possible to obtain a good fit for the model. The resulting indexes are: RMSEA (.00), NFI (.93), TLI (1.00) and CFI (1.00) (Figure 1 and Table 1).

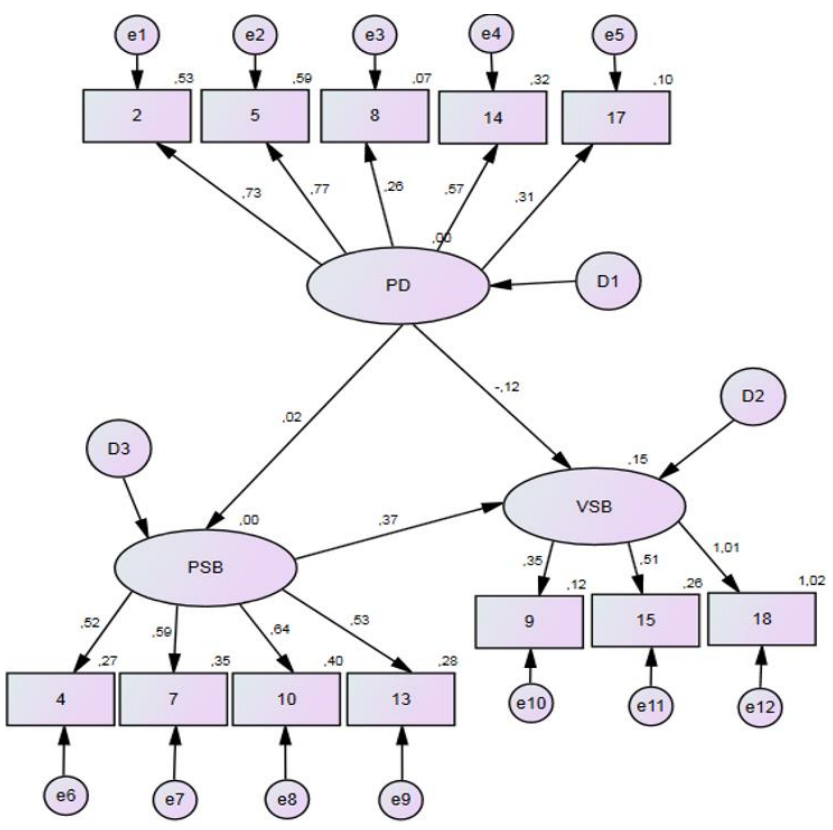

Figure 1. Confirmatory factor analysis of the TRANS-12 scale $(n 1=272)$ $(\mathrm{NFI}=.93 ; \mathrm{TLI}=1.00 ; \mathrm{CFI}=1.00 ; \mathrm{RMSEA}=.00)$.

Table 1. Comparison of indexes (RMSEA, NFI, TLI and CFI) between TRANS -18 and TRANS -12 in two different subsamples.

\begin{tabular}{llllll}
\hline & RMSEA & NFI & TLI & CFI \\
\hline TRANS-18 $\left(3\right.$ Factor; $\left.n_{1}=272\right)$ & .08 & .84 & .86 & .91 \\
TRANS-18 $\left(3\right.$ Factor; $\left.n_{2}=326\right)$ & .08 & .85 & .89 & .90 \\
TRANS-12 (3 Factor; $\left.n_{1}=272\right)$ & .00 & .93 & 1.00 & 1.00 \\
TRANS-12 $\left(3\right.$ Factor; $\left.n_{2}=326\right)$ & .03 & .93 & .95 & .95 \\
\hline
\end{tabular}

\subsubsection{Reliability}

Cronbach's $\alpha$ value is .79 (F1), .70 (F2 and F3) (Table 2). It can be seen that the values are equal to or higher than the recommended value of 0.70 (Nunnally \& Bernstein, 1994). 
Table 2. Descriptive statistics, reliability, confidence intervals, correlations between the three factors of the TRANS-12 and TRANS-18 scales and the factors of the SOFI, MBI-GS and MPS scales, plus the correlations matrix between the factors of the scales.

\begin{tabular}{|c|c|c|c|c|c|c|c|c|c|}
\hline & \multicolumn{3}{|c|}{ Original Study (Trans-18) } & \multicolumn{3}{|c|}{ Study $1\left(n_{1}=272\right)$} & \multicolumn{3}{|c|}{ Study $2\left(n_{1}=326\right)$} \\
\hline & F1 & F2 & F3 & F1 & F2 & F3 & F1 & F2 & F3 \\
\hline $\bar{M}$ & 10.40 & 15.04 & 25.00 & 10.07 & 12.86 & 11.61 & 9.89 & 14.58 & 12.08 \\
\hline$S D$ & 4.40 & 6.25 & 4.43 & 3.73 & 4.13 & 2.81 & 3.41 & 3.92 & 2.72 \\
\hline Reliability & .81 & .80 & .70 & .79 & .70 & .70 & .74 & .71 & .70 \\
\hline Confidence Interval & $.77-.84$ & $.75-.83$ & $.62-.74$ & $.74-.82$ & $.65-.74$ & $.64-.75$ & $.70-.80$ & $.65-.76$ & $.64-.74$ \\
\hline SOFI (F1-Lack of Energy) & $.38^{* *}$ & .07 & $-.30 * *$ & $.51 * *$ & -.02 & $-.13^{*}$ & --- & --- & --- \\
\hline SOFI (F2-Physical Fatigue) & $.33 * *$ & $-.15^{*}$ & $-.14^{*}$ & $.48^{* *}$ & -.02 & $-.21 * *$ & --- & --- & --- \\
\hline SOFI (F3-Physical Discomfort) & $.38^{* *}$ & .00 & $-.13 *$ & $.54 * *$ & -.02 & -.11 & --- & --- & --- \\
\hline SOFI (F4-Lack of Motivation) & $.33^{* *}$ & -.04 & $-.27 * *$ & $.46^{* *}$ & -.01 & $-.16^{* *}$ & --- & --- & --- \\
\hline SOFI (F5-Drowsiness) & $.34 * *$ & .05 & $-.25^{* *}$ & $.31 * *$ & -.05 & $-.20 * *$ & --- & --- & --- \\
\hline MBI-GS (F1-Exhaustion) & $.39 * *$ & $-.16^{*}$ & $-.16^{*}$ & $.57^{* *}$ & -.08 & $-.22 * *$ & $.40^{* *}$ & $-.23 * *$ & $-.24 * *$ \\
\hline MBI-GS (F2-Cynicism) & $.32 * *$ & -.06 & -.08 & $.43 * *$ & -.06 & $-.22 * *$ & $.32 * *$ & $-.19 * *$ & $-.22 * *$ \\
\hline MBI-GS (F3-Efficacy) & $-.17 * *$ & $.21 * *$ & $.22^{* *}$ & $-.17 * *$ & $.14^{*}$ & $.32 * *$ & -.12 & .00 & $-.21 * *$ \\
\hline MPS (Body) & --- & --- & --- & --- & --- & --- & $.39 * *$ & -.02 & -.02 \\
\hline MPS (Extremities) & --- & --- & --- & --- & --- & --- & $.34 * *$ & $-.18^{* *}$ & -.13 \\
\hline F1.-Psychophysiological disorders (PD) & 1.000 & --- & --- & 1.000 & --- & --- & 1.000 & --- & --- \\
\hline F2.-Personal safety behaviors (PSB) & -.06 & 1.000 & --- & .06 & 1.000 & --- & -.08 & 1.000 & --- \\
\hline F3.-Vehicle-related safety behaviors (VSB) & -.22 & .00 & 1.000 & -.14 & .31 & 1.000 & -.25 & .29 & 1.000 \\
\hline
\end{tabular}

F1.- Psychophysiological disorders (PD)

F2.- Personal safety behaviors (PSB)

F3.- Vehicle-related safety behaviors (VSB)

$* * p<.01 ; * p<.05$

\subsubsection{Evidence of validity}

Evidence of validity was calculated using correlations between the TRANS-12 scale and the external constructs and contrast scales used (Table 2).

We show sixteen significant correlations, of which nine are positive, e.g. lack of energy (SOFI) $(r=.51, p<.01)$ and exhaustion (MBI-GS) $(r=.55, p<.01)$. The seven negative significant correlations include, for instance, physical fatigue $(r=-.21, p<.01)$ and cynicism (MBI-GS) $(r=-.22, p<.01)$.

\section{Study 2}

\subsection{Objectives}

Objective-4: to analyze the internal structure of the 12item scale using CFA; Objective-5: to calculate reliability; and Objective-6: to show evidence of validity.

\subsection{Method}

\subsubsection{Participants}

A total of 326 transport drivers $(93.6 \%$ men, 6.4\% women) resident in Spain took part in the study (Study 2). Their sector distribution was as follows: general freight (26.7\%), dangerous freight $(5.7 \%)$, special freight $(4.2 \%)$, cranes $(3.5 \%)$, intra-urban line passengers $(21.3 \%)$, inter-urban line passengers $(11.1 \%)$, charter passengers $(6.7 \%)$, ambulances $(7.9 \%)$, taxis $(9.8 \%)$ and others $(3.1 \%)$. Their work in transport took place in the following areas: Europe $(9.6 \%)$, Spain $(22.7 \%)$, autonomous regions $(28.4 \%)$ and provinces $(39.3 \%)$. The average age was $40.97(S D=10.32)$.

\subsubsection{Measures}

The Spanish version of the TRANS-12 Scale, result of the study of the elimination of six items.

The Spanish version of the Maslach Burnout Inventory General Survey (MBI-GS; Salanova et al., 2000; Schaufeli et al., 1996).

The Spanish version of the Musculoskeletal Problems Scale (MPS-9; Robb \& Mansfield, 2007; Robert-Sentís, 2016), which has 9 items and 2 factors, the factors being body ( 4 items; $\alpha=.72$; e.g. "Neck") and extremities (5 items; .70; e.g. "Knees, one or both"). Responses are measured using a 5-point Likert scale (from 1-Never to 5-Always).

\subsubsection{Procedure}

The data were collected from a Spanish sample of professional drivers. Non-probabilistic sampling for accessibility was used.

\subsubsection{Data analysis}

The AMOS 23.0 program was used in Study $2\left(n_{1}=326\right)$ to calculate the AFC. The SPSS program (23.0) was also used to calculate the reliability of the factors and evidence of validity.

\subsection{Results}

\subsubsection{Confirmatory factor analysis}

Given the need to confirm the CFA structure of the TRANS-12 (Study 1, $n_{1}=272$ ), an analysis was performed on 
sample $2\left(n_{2}=326\right)$. The results obtained show a good fit for the trifactorial model judging by the indexes (NFI=.93; $\mathrm{TLI}=.95 ; \mathrm{CFI}=.95 ; \mathrm{RMSEA}=.03)($ Figure 2$)$.

\subsubsection{Reliability}

In this sample Cronbach's $\alpha$ value is .74(F1), .71(F2) and .70 (F3) (Table 2), which are equal to or higher than the recommended value of 0.70 (Nunnally \& Bernstein, 1994).

In table 3 , the descriptive statistics and the reliability coefficients of the three studies (Original, Study-1 and Study-2) are explained.

\subsubsection{Evidence of validity}

Table 2 shows the contrast scales. Evidence of validity has been calculated by correlations. Ten significant correlations are shown, of which four are positive, e.g. exhaustion (MBI-GS) $(r=.40, p<.01)$ and body (MPS) $(r=.39, p<.01)$. The six negatives include, for instance, cynicism (MBI-GS) $(r$ $=-.22, p<.01)$ and efficacy (MBI-GS) $(r=-.21, p<.01)$.

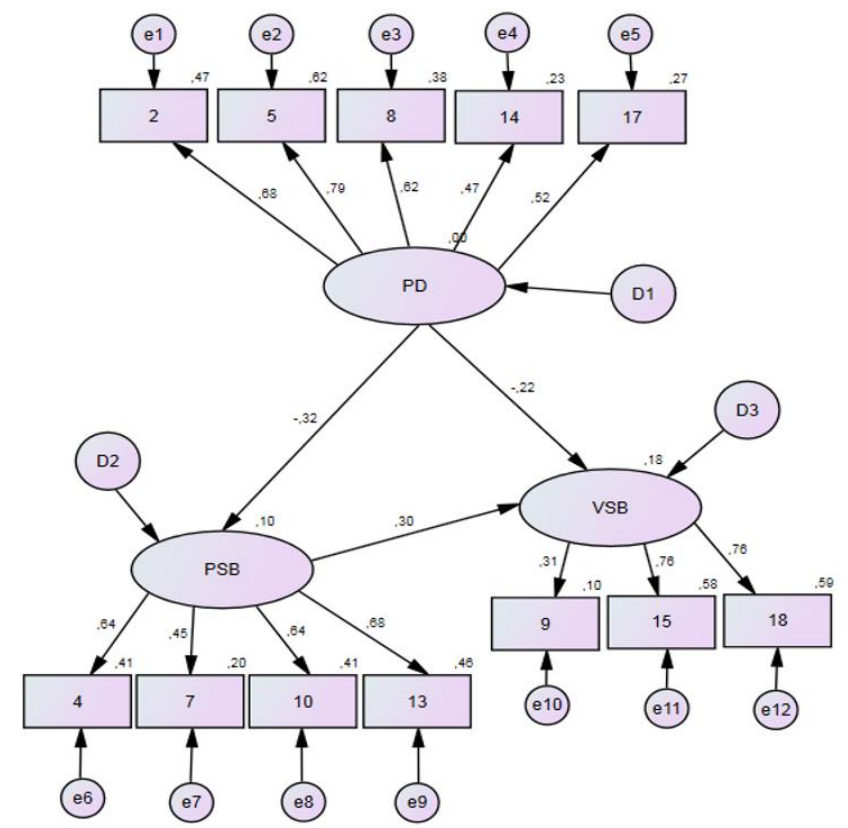

Figure 2. Confirmatory factor analysis of the TRANS-12 scale $\left(n_{2}=326\right)$ $(\mathrm{NFI}=.93 ; \mathrm{TLI}=.95 ; \mathrm{CFI}=.95 ; \mathrm{RMSEA}=.03)$

$\underline{\text { Table 3. Descriptive statistics and reliability values with Cronbach's alpha coefficient of tree studies. }}$

\begin{tabular}{|c|c|c|c|c|c|c|c|c|c|c|c|c|c|c|c|}
\hline \multirow[b]{2}{*}{ Variable } & \multicolumn{5}{|c|}{$\begin{array}{l}\text { (TRANS-18) } \\
\text { Original Study }\end{array}$} & \multicolumn{5}{|c|}{$\begin{array}{c}\text { (TRANS-12) } \\
\text { Study } 1(n 1=272)\end{array}$} & \multicolumn{5}{|c|}{$\begin{array}{c}\text { (TRANS-12) } \\
\text { Study } 2(n 1=326)\end{array}$} \\
\hline & Min & Max & M & $S D$ & $\alpha$ & Min & Max & M & $S D$ & $\alpha$ & Min & Max & M & $S D$ & $\alpha$ \\
\hline F1.Psychophysiological disorders (PD) & 6.00 & 30.00 & 10.40 & 4.40 & .81 & 5.00 & 25.00 & 9.88 & 3.35 & .79 & 5.00 & 24.00 & 8.99 & 3.81 & .74 \\
\hline F2.-Personal safety behaviors (PSB) & 6.00 & 30.00 & 15.04 & 6.25 & .80 & 4.00 & 20.00 & 14.44 & 3.93 & .70 & 3.00 & 15.00 & 7.85 & 3.08 & .71 \\
\hline F3.-Vehicle-related safety behaviors (VSB) & 14.00 & 30.00 & 25.00 & 4.43 & .70 & 3.00 & 20.00 & 11.99 & 2.77 & .70 & 4.00 & 20.00 & 14.79 & 3.03 & .70 \\
\hline SOFI (F1-Lack of Energy) & 1.00 & 25.00 & 4.85 & 4.88 & .80 & 1.00 & 30.00 & 8.23 & 6.58 & .84 & --- & --- & --- & --- & --- \\
\hline SOFI (F2-Physical Fatigue) & 1.00 & 25.00 & 3.82 & 3.85 & .77 & 1.00 & 25.00 & 3.82 & 3.85 & .70 & --- & --- & --- & --- & --- \\
\hline SOFI (F3-Physical Discomfort) & 1.00 & 25.00 & 6.39 & 6.02 & .81 & 1.00 & 25.00 & 6.39 & 6.02 & .80 & --- & --- & --- & --- & --- \\
\hline SOFI (F4-Lack of Motivation) & 1.00 & 25.00 & 5.62 & 5.36 & .80 & 1.00 & 25.00 & 5.62 & 5.36 & .70 & --- & --- & --- & --- & --- \\
\hline SOFI (F5-Drowsiness) & 1.00 & 30.00 & 7.12 & 6.50 & .87 & 1.00 & 26.00 & 7.22 & 6.12 & .87 & --- & --- & --- & --- & --- \\
\hline MBI-GS (F1-Exhaustion) & 1.00 & 28.00 & 9.40 & 6.08 & .83 & 1.00 & 30.00 & 11.59 & 6.85 & .86 & 1.00 & 29.00 & 12.35 & 7.32 & .88 \\
\hline MBI-GS (F2-Cynicism) & 1.00 & 21.00 & 6.21 & 5.19 & .82 & 1.00 & 24.00 & 5.18 & 4.77 & .86 & 1.00 & 23.00 & 6.22 & 5.66 & .85 \\
\hline MBI-GS (F3-Efficacy) & 10.00 & 36.00 & 28.86 & 5.13 & .79 & 6.00 & 36.00 & 24.32 & 6.68 & .80 & 8.00 & 32.00 & 22.32 & 5.98 & .79 \\
\hline MPS (Body) & --- & --- & --- & --- & --- & --- & --- & --- & --- & --- & 4.00 & 18.00 & 9.46 & 3.07 & .72 \\
\hline MPS (Extremities) & --- & --- & --- & --- & --- & --- & --- & --- & --- & --- & 5.00 & 20.00 & 8.53 & 2.97 & .70 \\
\hline
\end{tabular}

\section{Discussion (Study 1 and Study 2)}

\subsection{Summary and discussion of the results}

The main objective of this study was to analyze the factorial structure and other psychometric properties of the TRANS-18 scale, this initial version of 18 items was discarded because it did not have an adequate setting. Those elements that made it impossible to adjust the model in the original version were discarded. Therefore, a total of six elements were eliminated, which allowed obtaining a good fit for the model, giving rise to the Trans- 12 scale. The results suggest that the TRANS-12 scale has an internal structure of three factors, along with appropriate reliability and evidence of validity. It is an instrument for evaluating safe behaviors for personal and vehicle-related safety and security among drivers in the transport industry. Accordingly, the scale measures this construct from a behavioral and psychosociological approach to safety in professional drivers. It is the first instrument in Spanish to evaluate occupational safety in the transport industry.

Objective 1 (Study 1) was to analyze the internal structure of the original 18-item scale (TRANS-18) using CFA. The results discard the version with 18 items and three factors because it does not fit the model, so we analyzed and eliminated those items with inappropriate saturation. These modifications enabled the model to fit $(\mathrm{NFI}=.84$; $\mathrm{TLI}=.86$; CFI $=.91$; and RMSEA $=.08)$, resulting in the 12-item scale analyzed in Study 2.

Objective 4 (Study 2) was analogous to Objective 1 (Study 1) applied to the 12-item scale (TRANS-12). The re- 
sults indicate that the scale's trifactorial structure has a good fit $(\mathrm{NFI}=.93$; $\mathrm{TLI}=.95$; $\mathrm{CFI}=.95$; and RMSEA $=.03$ ). Thus the superiority of the internal structure of the 12 -item scale is corroborated with respect to the 18 -item scale, confirming Objective 4.

The first factor of the scale (F1. Psychophysiological disorders) is related to the set of symptoms the driver can suffer, the second (F2. Personal safety behaviors) is linked to responsible personal conduct at work, and the third (F3. Vehicle-related safety behaviors) corresponds to safe behavior and risk prevention at work.

Objective 2 (Study 1) and Objective 5 (Study 2) were to analyze the reliability of both scales. The reliability of the original 18-item scale is .79 (F1) and .70 (F2 and F3), whereas the reliability of the TRANS-12 is .74 (F1), .71 (F2) and .70 (F3). These results reveal that the reliability of the scales is optimal, so Objectives 2 and 5 are confirmed.

Finally, Objective 3 (Study 1) and Objective 6 (Study 2) were to provide evidence of validity for both versions. In general the results show a significant association between the factors of the scale analyzed and other external scales and correlates. Consequently both objectives (3 and 6) are confirmed.

\subsection{Limitations and suggestions for future research}

Firstly, regarding the techniques for obtaining information, the association between variables may be higher due to common-method variance caused by the use of selfreporting. However, the incorporation of external correlates which mostly correlate with the scales is aimed at controlling the effects of using this technique.

Secondly, in order to increase the external validity of the results, random sampling procedures should be used. However, it is noteworthy that the use of this type of sampling does not seriously threaten the validity of the investigation. Thirdly, the TRANS-12 subscales and items should be studied in different groups of immigrant drivers, since they are becoming increasingly represented in the industry and come from countries and cultures where safe behavior at work has different connotations. Fourthly, it would be useful to evaluate the possible relationship between the TRANS-12 scale and relevant aspects of the transport industry, such as lack of safety motivation, long working hours and other substantial issues. Finally, it would be interesting to evaluate the relationship of certain personality traits (impulsiveness, locus of control, etc.) as background variables as regards safe behaviors and psychophysiological disorders in drivers in the transport industry.

\subsection{Conclusion}

Overall, the study confirms the adequacy of the psychometric properties of the TRANS-12 scale and its usefulness in determining safe work behavior in the transport industry (Table 4). The analysis has provided evidence of a trifactorial structure for the two scales, both the original and the abbreviated version, and the number of items has been reduced from 18 to 12. Furthermore, the three factors of the internal structure of the scale have optimal reliability indexes. All this points to the TRANS-12 scale as being a brief instrument, quick to apply and interpret and easy to understand.

Table 4. TRANS-12: Scale items in English and Spanish.

\section{Items}

1. - Mi trabajo me ha producido algún trastorno de ansiedad [My job has at some time caused me anxiety problems] (PD)

2. - Rehuyo conducir bebiendo un refresco [I try not to drive while drinking a soft drink] (PSB)

3. - Mi trabajo me ha producido algún trastorno de estrés [My job has at some time caused me stress problems] (PD)

4. - Eludo conducir fumando y no tengo el cigarro, puro, purete... en la mano [I avoid driving whilst smoking and I don't hold the cigarette, cigar in my hand] (PSB)

5. - Mi trabajo me ha producido algún trastorno digestivo (por ejemplo, restreñimiento) [My job has at some time caused me digestive problems (e.g. constipation)] (PD)

6. - Tengo precaución al bajar de mi vehículo [I am careful when I get off/out of my vehicle] (VSB)

7. - Evito conducir después de haber comido copiosamente $[I$ avoid driving after a large meal] (PSB)

8. - Eludo conducir comiendo un bocata, una pasta, etc. [I avoid driving whilst eating a sandwich, a cake, etc] (PSB)

9. - Mi trabajo me ha producido algún trastorno muscular y/o esquelético (por ejemplo, lumbalgias, tendinitis, etc.) [My job has at some time caused me muscular and/or skeletal pain (e.g. lower back pain, tendinitis, etc.)] (PD)

10.- Al día conduzco las horas establecidas legalmente [I drive the statutory number of hours per day] (VSB)

11.- Mi trabajo me ha producido algún trastorno de hipertensión (por ejemplo, tensión alta, etc.) [My job has at some time caused me hypertension problems (e.g. high blood pressure, etc)] (PD)

12.- Hago un descanso después de cada 4 horas de conducción [I take a rest after every 4 hours of driving] (VSB)

These findings provide valuable guidance to researchers and practitioners when it comes to identifying mechanisms whereby they can promote safe behavior in professional drivers. In short, the TRANS-12 scale takes on particular importance because of its applicability, since detecting the level of safe behavior at work is the first step toward implementing specific actions aimed at risk prevention and the promotion of safe behavior as part of the strategic management of human resources in the transport industry. 


\section{References}

Ahsberg, E. (2000). Dimensions of fatigue in different working populations. Scandinavian Journal of Psychology 41, 231-241. http:/ /dx.doi.org/10.1111/1467-9450.00192

Ahsberg, E., Gamberale, F., \& Kjellberg, A. (1997). Perceived quality of fatigue during different occupational tasks. Development of a questionnaire. International Journal of Industrial Ergonomics, 20, 121-135. http:/ /dx.doi.org/10.1016/ S0169-8141(96)00044-3

Álava Urrburu, C., Huerta Rodríguez, I., \& Noval Vallina, M. (2011). Revisión bibliográfica exploratoria sobre los criterios de aptitud en conductores profesionales con enfermedad psiquiátrica. Medicina $y$ Seguridad del Trabajo, 57, 41-62. http://dx.doi.org/ 10.4321/s0465546x2011000100006

Alperovitch-Najenson, D., Santo, Y., Masharawi, Y., Katz-Leurer, M., Ushvaev, D., \& Kalichman, L. (2010). Low back pain among professional bus drivers: ergonomic and occupational-psychosocial risk factors. IMAJ-Israel Medical Association Journal, 12, 26-31.

Boada-Grau, J., Sánchez-García, J. C., Prizmic-Kuzmica, A. J., \& VigilColet, A. (2012). Health and safety at work in the transport industry (Trans-18): factorial structure, reliability and validity. The Spanish Journal of Psychology, 15, 357-366. http://dx.doi.org/10.5209/rev_SJOP.2012.v15.n1.37342

Castilla, O. (2012). Observation of unsafe behavior at work: a methodological analysis. Universitas Psychologica, 11, 311-321.

Catarino, R., Spratley, J., Catarino, I., Lunet, N., \& Pais-Clemente, M. (2014). Sleepiness and sleep-disordered breathing in truck drivers. Sleep and Breathing, 18, 59-68. http://dx.doi.org/10.1007/s11325-013-0848-x

Cendales-Ayala, B., Useche, S. A., Gómez-Ortiz, V., \& Bocarejo, J. P. (2017). Bus operators' responses to job strain: An experimental test of the job demand-control model. Journal of Occupational Health Psychology, 22, 518-527. http:// dx.doi.org/10.1037/ocp0000040

Chai, J., Qu, W., Sun, X., Zhang, K., \& Ge, Y. (2016). Negativity Bias in Dangerous Drivers. PLoS One, 11, e0147083 http://dx.doi.org/10.1371/journal.pone.0147083

Chen, C. C., Shiu, L. J., Li, Y. L., Tung, K. Y., Chan, K. Y., Yeh, C. J., \& Wong, R. H. (2010). Shift work and arteriosclerosis risk in professional bus drivers. Annals of Epidemiology, 20, 60-66.

Clark, O. L., Zickar, M. J., \& Jex, S. M. (2014). Role definition as a moderator of the relationship between safety climate and organizational citizenship behavior among hospital nurses. Journal of Business and Psychology, 29, 101-110. http://dx.doi.org/10.1007/s10869-013-9302-0

Credo, K. R., Armenakis, A. A., Feild, H. S., \& Young, R. L. (2010). Organizational ethics, leader-member exchange, and organizational support: Relationships with workplace safety. Journal of Leadership \& Organizational Studies, 17, 325-334. https://doi.org/10.1177/1548051810366712

Department of Labor, Bureau of Labor Statistics (US) (2016). Employerreported Workplace Injuries and Illnesses 2015 (USDL-16-2056). Available

https://www.bls.gov/news.release/archives/osh_10272016.pdf (accessed 18 January 2017).

Đinđić, N., Jovanović, J., Đinđić, B., Jovanović, M., Pešić, M., \& Jovanović, J. J. (2013). Work stress related lipid disorders and arterial hypertension in professional drivers: A cross-sectional study. Vojnosanitetski pregled, 70, 561-568. http://dx.doi.org/10.2298/VSP1306561D

Dorn, L., Stephen, L., af Wåhlberg, A., \& Gandolfi, J. (2010). Development and validation of a self-report measure of bus driver behaviour. Ergonomics, 53,

1420-1433. http://dx.doi.org/10.1080/00140139.2010.532882

Dorrian, J., Baulk, S. D., \& Dawson, D. (2011). Work hours, workload, sleep and fatigue in Australian Rail Industry employees. Applied Ergonomics, 42, 202-209. http://dx.doi.org/10.1016/j.apergo.2010.06.009

European Comission (Employment, Social Affairs \& Inclusion) (2014). Communication from the Commission to the European Parliament, the Council, the European Economic and Social Committee and the Committee of the Regions on an EU Strategic Framework on Health and Safety at Work 2014-2020 (COM 2014, 0332 final). Available at: http://eur-lex.europa.eu/legal-
content/EN/TXT/PDF/?uri=CELEX:52014DC0332 (accessed 25 January 2017)

Eurostat (2016). Accidents at Work Statistics - Statistics Explained. Available at: http://ec.europa.eu/eurostat/statisticsexplained/index.php/Accidents_at_work_statistics (accessed 28 January 2017).

Fan, X., \& Sivo, S.A. (2007). Sensitivity of fit indices to model misspecification and model types. Multivariate Behavioral Research, 42, 509-529.

García-Herrero, S., Lopez-Garcia, J. R., Herrera, S., Fontaneda, I., Báscones, S. M., \& Mariscal, M. A. (2017). The Influence of Recognition and Social Support on European Health Professionals' Occupational Stress: A Demands-Control-Social Support-Recognition Bayesian Network Model. BioMed Research International, 2017, 1-13. https://doi.org/10.1155/2017/4673047

Gershon, P., Shinar, D., Oron-Gilad, T., Parmet, Y., \& Ronen, A. (2011). Usage and perceived effectiveness of fatigue countermeasures for professional and nonprofessional drivers. Accident Analysis \& Prevention, 43, 797-803. http://dx.doi.org/10.1016/j.aap.2010.10.027

Gómez-Ortiz, V., Cendales, B., Useche, S., \& Bocarejo, J. P. (2018). Relationships of working conditions, health problems and vehicle accidents in bus rapid transit (BRT) drivers. American Journal of Industrial Medicine, 61, 336-243. https://doi.org/10.1002/ajim.22821

González, J. L., Moreno, B., Garrosa, E., \& López, A. (2005). Spanish version of the Swedish Occupational Fatigue Inventory (SOFI): Factor replication, reliability and validity. International Journal of Industrial Ergonomics, 35, 737-746. http://dx.doi.org/10.1016/j.ergon.2005.02.007

Häusser, J. A., Mojzisch, A., Niesel, M., \& Schulz-Hardt, S. (2010). Ten years on: A review of recent research on the Job Demand-Control (Support) model and psychological well-being. Work \& Stress, 24, 1-35. http://dx.doi.org/10.1080/02678371003683747

Hirata, R. P., Sampaio, L. M. M., Leitão Filho, F. S. S., Braghiroli, A., Balbi, B., Romano, S., Insalaco, G., \& Oliveira, L. V. F. D. (2012). General characteristics and risk factors of cardiovascular disease among interstate bus drivers. The Scientific World Journal, 2012, 1-7. http://dx.doi.org/10.1100/2012/216702

Instituto Nacional de Seguridad e Higiene en el Trabajo (INSHT) (2015) Estrategia Española de Seguridad y Salud en el Trabajo 2015-2020. Gobierno de España. Available at: http://www.insht.es/InshtWeb/Contenidos/Documentacion/ESTRA TEGIA\%20SST\%2015_20.pdf (accessed 22 January 2017).

Jadhav, A. V. (2016). Comparative cross-sectional study for understanding the burden of low back pain among public bus transport drivers. Indian Journal of Occupational and Environmental Medicine, 20, 26-30. doi: 10.4103/0019-5278.183833

Karasek, R. A. (1979). Job demands, job decision latitude, and mental strain: Implications for job redesign. Administrative Science Quarterly, 24 285-308.

Kresal, F., Roblek, V., Jerman, A., \& Meško, M. (2015). Lower back pain and absenteeism among professional public transport drivers. International Journal of Occupational Safety and Ergonomics, 21, 166-172. https://doi.org/10.1080/10803548.2015.1029289

Lévy-Mangin, J.P., \& Varela-Mallou, J. (2006). Modelling covariance structures in the social sciences. Topics essential, advanced and special contributions. Madrid: Gesbiblo.

Lin, Y. J., Wu, W.T., Liou, S. H., \& Guo, Y. L. (2017). A cohort study of job stress and fatigue on health psychology among professional drivers. Occupational \& Enviromental Medicine, 74, A13. http://dx.doi.org/10.1136/oemed-2017-104636.34

Nahrgang, J. D., Morgeson, F. P., \& Hofmann, D. A. (2011). Safety at work: a meta-analytic investigation of the link between job demands, job resources, burnout, engagement, and safety outcomes. Journal of Applied Psychology, 96, 71-94. http://dx.doi.org/10.1037/a0021484

Nunnally, J. C., \& Bernstein, I. H. (1994). Psychometric theory. New York: McGraw-Hill.

Occupational Safety and Health (OSH) (2014). Strategic Framework 2014 2020 - Employment, Social Affairs \& Inclusion. European Commission. Available 
http://ec.europa.eu/social/main.jsp?catId=151\&langId=en (accessed 17 January 2017).

Öz, B., Özkan, T., \& Lajunen, T. (2010). Professional and non-professional drivers' stress reactions and risky driving. Transportation Research Part F: Traffic Psychology and Behaviour, 13, 32-40. http://dx.doi.org/10.1016/j.trf.2009.10.001

Ramírez, M. G., Hernández, R. L., Reducindo, M. M., Genchi, P. C., Mendoza, R. V., \& Jaimes, F. G. (2013). Estrés cotidiano en trabajadores del volante. Summa Psicológica UST (En línea), 10, 85-90.

Robb, M. J. M., \& Mansfield, N. J. (2007). Self-reported musculoskeletal problems amongst professional truck drivers. Ergonomics, 50, 814-827.

Robert-Sentís, Ll. (2016). Occupational health professional drivers road transport. Unpublished Doctoral Thesis. Rovira i Virgili University.

Salanova, M., Schaufeli, W. B., Llorens, S., Peiró, J. M., \& Grau, R. (2000). From burnout to engagement: A new perspective?. Journal of Work and Organizational Psychology, 16, 117-134.

Schaufeli, W. B., Leiter, M. P., Maslach, C., \& Jackson, S. E. (1996). Maslach Burnout Inventory - General Survey. In C. Mas1ach, S. E. Jackson, \& M. P. Leiter (Eds.), The Maslach Burnout Inventory- Test Manual (3rd Ed.). Palo Alto, CA: Consulting Psychologists Press.

Schumacker, R. E., \& Lomax, R. G. (1996). A beginner's guide to structural equation modeling. Mahwah, NJ: Lawrence Erlbaum Associates.

Seibokaite, L., \& Endriulaitiene, A. (2012). The role of personality traits, work motivation and organizational safety climate in risky occupational performance of professional drivers. Baltic Journal of Management, 7, 103118. http:// dx.doi.org/10.1108/17465261211195892

Shen, S., Li, Y., Zhou, M., Zhang, C., Jiang, Y., \& Kang, Y. (2013). Depression Status and Associated Factors in Chinese Occupational Truck
Drivers. Cell Biochemistry and Biophysics, 67, 1497-1500. https://doi.org/10.1007/s12013-013-9651-3

Siedlecka, J., Bortkiewicz, A., Gadzicka, E., \& Makowiec-Dabrowska, T. (2012). Job stress and blood pressure in public transport drivers. International Journal of Psychophysiology, 85, 409-409.

Tamrin, S. B. M., Yokoyama, K., Aziz, N., \& Maeda, S. (2014). Association of risk factors with musculoskeletal disorders among male commercial bus drivers in Malaysia. Human Factors and Ergonomics in Manufacturing \& Service Industries, 24, 369-385. http://dx.doi.org/10.1002/ hfm.20387

Ulhôa, M. A., Marqueze, E. C., Kantermann, T., Skene, D., \& Moreno, C. (2011). When does stress end? Evidence of a prolonged stress reaction in shiftworking truck drivers. Chronobiology International, 28, 810-818. http://dx.doi.org/10.3109/07420528.2011.613136

Useche, S. A., Cendales, B., \& Gómez, V. (2017a). Measuring fatigue and its associations with job stress, health and traffic accidents in professional drivers: The case of BRT operators. EC Neurology, 4.4, 103-118.

Useche, S., Cendales, B., \& Gómez, V. (2017b). Work stress, fatigue and Risk Behaviors at the Wheel: Data to assess the association between psychosocial work factors and risky driving on Bus Rapid Transit drivers. Data in Brief, 15, 335-339. http://dx.doi.org/10.1016/j.aap.2017.04.023.

Wagstaff, A. S., \& Lie, J. A. S. (2011). Shift and night work and long working hours-a systematic review of safety implications. Scandinavian Journal of Work, Environment \& Health, 173-185. http://dx.doi.org/10.5271/sjweh.3146

Winkleby, M. A., Ragland, D. R., Fisher, J. M., \& Syme, S. L. (1988). Excess risk of sickness and disease in bus drivers: a review and synthesis of epidemiological studies. International Journal of Epidemiology, 17, 255-262. http://dx.doi.org/10.1093/ije/17.2.255 